\title{
Five Indigenous Plants of Pakistan with Antinociceptive, Anti-Inflammatory, Antidepressant, and Anticoagulant Properties in Sprague Dawley Rats
}

\author{
Hammad Ismail, ${ }^{1}$ Ammara Rasheed, ${ }^{2}$ Ihsan-ul Haq, ${ }^{3}$ Laila Jafri, ${ }^{4}$ Nazif Ullah, \\ Erum Dilshad, ${ }^{6}$ Moniba Sajid, $^{2}$ and Bushra Mirza ${ }^{2}$ \\ ${ }^{1}$ Department of Biochemistry and Biotechnology, University of Gujrat, Gujrat 50700, Pakistan \\ ${ }^{2}$ Department of Biochemistry, Quaid-i-Azam University, Islamabad 45320, Pakistan \\ ${ }^{3}$ Department of Pharmacy, Quaid-i-Azam University, Islamabad 45320, Pakistan \\ ${ }^{4}$ Department of Biochemistry, Bahauddin Zakariya University, Multan 60000, Pakistan \\ ${ }^{5}$ Department of Biotechnology, Abdul Wali Khan University, Mardan, Pakistan \\ ${ }^{6}$ Department of Bioinformatics and Biosciences, Capital University of Science and Technology, Islamabad, Pakistan
}

Correspondence should be addressed to Bushra Mirza; bushramirza@qau.edu.pk

Received 24 June 2017; Revised 11 October 2017; Accepted 26 October 2017; Published 23 November 2017

Academic Editor: Ken Yasukawa

Copyright (C) 2017 Hammad Ismail et al. This is an open access article distributed under the Creative Commons Attribution License, which permits unrestricted use, distribution, and reproduction in any medium, provided the original work is properly cited.

\begin{abstract}
Five medicinal plants of Pakistan were investigated for their antinociceptive, anti-inflammatory, antidepressant, and anticoagulant potential. Antinociceptive activity was estimated by hot plate and writhing assay. In hot plate assay, Quercus dilatata (52.2\%) and Hedera nepalensis (59.1\%) showed moderate while Withania coagulans (65.3\%) displayed a significant reduction in pain. On the other hand, in writhing assay, Quercus dilatata (49.6\%), Hedera nepalensis (52.7\%), and Withania coagulans (62.0\%) showed comparative less activity. In anti-inflammatory assays crude extracts showed significant edema inhibition in a dose dependent manner. In carrageenan assay, the highest activity was observed for Withania coagulans (70.0\%) followed by Quercus dilatata $(66.7 \%)$ and Hedera nepalensis (63.3\%). Similar behavior was observed in histamine assay with percentage inhibitions of $74.3 \%$, $60.4 \%$, and $63.5 \%$, respectively. Antidepressant activity was estimated by forced swim test and the most potent activity was revealed by Withania coagulans with immobility time 2.2s (95.9\%) followed by Hedera nepalensis with immobility time 25.3s (53.4\%). Moreover, the crude extracts of Fagonia cretica (74.6\%), Hedera nepalensis (73.8\%), and Phytolacca latbenia (67.3\%) showed good anticoagulant activity with coagulation times $86.9 \mathrm{~s}, 84.3 \mathrm{~s}$, and $67.5 \mathrm{~s}$, respectively. Collectively, the results demonstrate that these five plants have rich medicinal constituents which can be further explored.
\end{abstract}

\section{Introduction}

Since the beginning of human civilization medicinal plants have been used for therapeutic purposes against different ailments; therefore they are considered to be one of the oldest form of human healthcare known to date [1]. It is also a matter of fact that medicinal plants and their products contribute more than half of all clinically administered drugs of modern day. According to an estimate $40 \%$ of new drugs approved during last two decades were of natural origin [2]. More precisely, between 1983 and 1994, 39\% of the 520 newly approved drugs were either natural products themselves or their derivatives and $40-80 \%$ of drugs developed against bacterial infections and cancer were of natural origin, which indicates that the use of natural products in treating human ailments has been making rapid progress and getting popular with the passage of time [3-7]. Therefore, plants and their products not only hold a substantial position in drug discovery but also can play a dynamic role in the revenue generation and improving the economic conditions of developing countries like Pakistan [1].

Fortunately, Pakistan is gifted with a rich flora of almost 5700 species of which around 2000 are reportedly medicinal plants. It is also matter of fact that, in Pakistan, over $40 \%$ 
of the population especially those living in rural areas are getting health care by local healers (Hakims), who prescribe herbal preparations [8]. However, the revenue generated by Pakistan is far lower than the trade in medicinal plants made by India and China recently [1]. This may be due to the lack of exploration of new medicinal plants or evaluation of the existing medicinal plants for their potential properties against different ailments. Therefore, based upon the knowledge from local healers and the available literature, five medicinal plants (Quercus dilatata, Fagonia cretica, Hedera nepalensis, Phytolacca latbenia, and Withania coagulans) were selected from different areas of Pakistan for the evaluation of antinociceptive, anti-inflammatory, antidepressant, and anticoagulant properties in Sprague Dawley rats.

Quercus dilatata Linn. is commonly called holly oak, green oak, or moru oak [9]. The tree produced galls which can be used against dysentery, chronic diarrhea, hemorrhages, and asthma [10]. This plant is also reported for its wound healing ability in rats and antioxidant enzymes activation [11, 12]. Fagonia cretica Linn, family Zygophyllaceae [13] commonly known as "Dhamasa" in Pakistan, is used against thirst, vomiting, dysentery, typhoid, toothaches, and skin diseases [14]. There are other ailments for which this plant is reported to be effective, including but not limited to neck swellings, cancer [15], snake bite [16], diuretic, analgesic, antipyretic, antidote, antiseptic, tonic, bitter, antiasthmatic, stomachic, and stimulant [17]. It also contains antioxidants and can be used as blood purifier and against scabies [18-20]. Hedera nepalensis $\mathrm{K}$ Koch. Is from Araliaceae family and popular as Himalayan Ivy or Nepalese Ivy [21]. In Pakistan, this plant is traditionally used against cancer and diabetes and as purgative [22, 23]. Some parts of this plant like leaves and berries are known to be stimulating, febrifuge, diaphoretic, antispasmodic, cathartic, and hypoglycemic $[24,25]$. H. nepalensis is also effective against fever, rheumatism, and pulmonary infection [26]. The indigenous plant Phytolacca latbenia is an abundant resource in Pakistan, distributed across more than 13,200 sq km, from an elevation of 1500-3000 m in the Murree, Galyat, Swat, Dir, Kaghan, and Kashmir hills [27]. This species has been known for its anti-inflammatory activities and has been widely used as traditional medicine by local community in Pakistan. Phytochemical analysis showed that $P$. latbenia is rich in saponins and terpenoids $[28,29]$. Oil from the root is also an important product which is used for the treatment of pain in joints. Root of this plant is also used for the production of a resinoid substance called phytolaccin, which is used in medicines and to dilute belladonna (http://www.tropicos.org). Withania coagulans (Stocks) Dunal belongs to family Solanaceae, commonly known as paneer (cheese maker) in Punjab [30]. This plant has been very popular amongst local healers in Pakistan. Its fruits are applied in folk medicine on wound and are used in asthma. Fruits are also reported to be diuretic, hypoglycemic, and hypolipidemic [31]. Other ailment in which this plant can be effective includes liver troubles, diabetes, dental problems, inflammations, and depression [31-37].

\section{Methods}

2.1. Plant Material. In the present study, five plants Quercus dilatata, Hedera nepalensis, Fagonia cretica, Phytolacca latbenia, and Withania coagulans were selected on the basis of their use in folk medicine. These plants were identified at the Department of Plant Sciences, Quaid-i-Azam University, Islamabad, Pakistan, by Professor Dr. Rizwana Aleem Qureshi (taxonomist). Their voucher specimen numbers were deposited in the "Herbarium of Medicinal Plants of Pakistan" in QAU Islamabad, Pakistan.

2.2. Extraction. Preparation of extracts was carried out by maceration. Briefly for Q. dilatata, leaves were taken while for the rest of the plants aerial part of the plants was taken and was dried under the shade. The plant material was then coarsely powdered and $200 \mathrm{~g}$ of it was soaked in $500 \mathrm{ml}$ of solvent mixture containing methanol and chloroform $(1: 1)$. After five days, extract was filtered by using Whatman filter paper number 1 . The filtrate was then concentrated with rotary evaporator at $40^{\circ} \mathrm{C}$ under low pressure. These dried crude extracts were named, respectively, with reference to plant and were stored at $4^{\circ} \mathrm{C}$ for further studies.

2.3. Preparation of Controls and Samples. Stock solution of each extract was prepared as $100 \mathrm{mg} / \mathrm{ml}$ while the standard drugs (Morphine, Aspirin, Fluoxetine HCl, Chlorpheniramine maleate, and diclofenac potassium) were prepared as $50 \mathrm{mg} / \mathrm{ml}$ in normal saline $(0.9 \%)$. The extracts and standard drugs were administered orally as per rat's body weight. Three different concentrations of the extracts $(200 \mathrm{mg} / \mathrm{Kg}$, $100 \mathrm{mg} / \mathrm{Kg}$, and $50 \mathrm{mg} / \mathrm{Kg}$ ) were used to determine the potential effect of the plants while the standards drugs were administered as $10 \mathrm{mg} / \mathrm{Kg}, 5 \mathrm{mg} / \mathrm{Kg}$, and $2.5 \mathrm{mg} / \mathrm{Kg}$, respectively. The normal/negative control rats were administered with saline $(0.9 \%)$.

2.4. Animals. Sprague Dawley rats (180-220 g) of either sex were randomly selected and designated as control and treatment groups (seven rats in each group). The animals were kept in aluminum cages (grade 304) under hygienic conditions maintained at $25 \pm 2{ }^{\circ} \mathrm{C}$ with a $12 \mathrm{~h}$ light/dark cycle at Primate Facility of Quaid-i-Azam University Islamabad, Pakistan. The rats were well fed and bred in standard conditions with water ad libitum and standard diet. The study design was approved by the Institutional Ethics and Biosafety Committee $(\mathrm{BCH}=0275)$, and all the precautions were carried to minimize animal suffering.

2.5. Acute Toxicity Test. To test the acute toxicity of plant extracts a single dose of each extract $(400 \mathrm{mg} / \mathrm{Kg})$ was administered orally to all rats in each group. The rats were monitored for any behavioral changes and mortality at interval of $0,4,8,12,16$, and $24 \mathrm{~h}$. The animals were further kept in observation for the next seven days for any symptoms of delayed toxicity or mortality.

\subsection{Antinociceptive Activity}

2.6.1. Hot Plate Assay. Hot plate test was used to determine the antinociceptive activity of selected medicinal plant as reported earlier [38]. Animal were divided into groups having seven rats in each. Group 1 and groups II received 
normal saline (negative control) and morphine (positive control), respectively. Each remaining group received different plant extract with three different concentrations $(200 \mathrm{mg} / \mathrm{Kg}$, $100 \mathrm{mg} / \mathrm{Kg}$, and $50 \mathrm{mg} / \mathrm{Kg}$ ). Prior to experiment initial latency time (ILT) of animals was measured on hot plate set at $52 \pm 1^{\circ} \mathrm{C}$ and rats having latency time more than $15 \mathrm{~s}$ were excluded. After 30 minutes of oral dosage, rats were placed on hot plate under same conditions and data was recorded in the form of licking or jumping response (either comes first). This time was regarded as experimental latency time (ELT). ELT was measured at interval of $0 \mathrm{~min}, 30 \mathrm{~min}$, $60 \mathrm{~min}$, and $120 \mathrm{~min}$. A cutoff period of $25 \mathrm{~s}$ was chosen to avoid tissue damage. Percentage analgesia was measured by following formula.

$$
\% \text { analgesia }=\left[\left(\frac{\mathrm{ELT}-\mathrm{ILT}}{\mathrm{ILT}}\right) \times 100\right] .
$$

2.6.2. Writhing Assay. Rat writhing assay was performed by the previously reported method [39] at $200 \mathrm{mg} / \mathrm{Kg}$ concentration of extracts. Briefly, animals were divided into controls and experimental groups followed by oral administration of morphine, saline, and plant crude extracts, respectively. After $30 \mathrm{~min}$, each rat was injected intraperitoneally with $0.6 \%$ analytical grade acetic acid and rats were housed in a flat glass cylinder. Data was recorded by counting writhing movements which is characterized by abdominal contraction and stretching of hind limbs [40]. Percentage activity was calculated by following formula.

$$
\% \text { analgesia }=\left[\left(\frac{\mathrm{Wc}-\mathrm{Ws}}{\mathrm{Wc}}\right) \times 100\right],
$$

where Wc represents mean value of saline group and Ws represents mean value of standard or extract group.

\subsection{Anti-Inflammatory Activity}

2.7.1. Carrageenan Assay. Anti-inflammatory activity of plants was evaluated by carrageenan induced edema test [41]. Sixty minutes before carrageenan injection standard drugs and crude extracts were administered orally. First and second group received saline and diclofenac potassium. Each remaining group was administered with different plant extracts (p.o). Right paw of each rat was injected with $0.1 \mathrm{ml}$ (1\%) carrageenan for edema induction. The paw volume was measured before and after the carrageenan induction at $0 \mathrm{~h}$, $1 \mathrm{~h}, 2 \mathrm{~h}, 3 \mathrm{~h}$, and $4 \mathrm{~h}$ by using Plethysmometer (UGO 7140, Basile) [7]. The percent inhibition of edema was calculated by using the following relation:

$$
\text { Percent edema inhibition }=\left[\frac{\text { N.C }- \text { S.G }}{\text { N.C }}\right] \times 100 \text {, }
$$

where N.C represents negative control group and S.G represents sample group.

2.7.2. Histamine Assay. In histamine assay, edema was induced by injecting $0.1 \mathrm{ml}$ of histamine $(1 \mathrm{mg} / \mathrm{ml})$ into the left hind paw of each rat [42]. 1st group received normal saline (negative control; $10 \mathrm{ml} / \mathrm{Kg}$ ) and 2 nd group received chlorpheniramine maleate (positive control; $10 \mathrm{mg} / \mathrm{Kg}$ ). Each extract was fed orally to separate group (rats =7) and edema was measured and calculated at $0 \mathrm{~min}, 30 \mathrm{~min}, 60 \mathrm{~min}$, $90 \mathrm{~min}$, and $120 \mathrm{~min}$, respectively, as described above in carrageenan assay.

2.8. Antidepressant Activity. Antidepressant activity of the extracts was investigated by forced swim assay as reported earlier [38]. Briefly, one day before experiment, preswim test was performed in $21 \times 46 \mathrm{~cm}$ glass tank filled $(30 \mathrm{~cm}$ depth) with warm water $\left(35^{\circ} \mathrm{C}\right)$. Animals were forced to swim in tank for 10 minutes, dried with towel, and housed back in aluminum cages. On experimental day, animal groups were orally administered with saline, Fluoxetine $\mathrm{HCl}$, and plants extracts, respectively. After 30 minutes animals were released in swim tank and immobility time was calculated.

2.9. Anticoagulant Activity. Capillary method was used to investigate the anticoagulant potential of crude extracts as reported by Ismail and Mirza [43]. After 60 minutes of oral administration with saline (negative control), Aspirin (positive control), and crude extracts in respective groups tail of each animal was pierced by sterile lancet. The blood drop was filled into capillary tube. Then a small piece of capillary tube was broken and the same was repeated, till fibrin thread was formed. Time interval between tail pricking and the fibrin formation was recorded.

2.10. Statistical Significance Analysis. The data was presented as mean with standard deviation and was analyzed using ANOVA followed by Tukey multiple comparison test. The results were considered to be significant when $p<0.05$.

\section{Results and Discussion}

3.1. Acute Toxicity Test. No mortality was observed for any of the crude extract at $400 \mathrm{mg} / \mathrm{K}$ (p.o). Neither of the extracts produces prominent changes in behavior during the time of observation.

\subsection{Antinociceptive Activity}

3.2.1. Hot Plate Assay. Hot plate assay is the widely used oldest method to measure nociception in rodents [44]. Latency time at different interval was recorded and presented in Table 1. The extracts showed time and concentration dependent activity which became maximum at $60 \mathrm{~min}$ as shown in Figure 1. The results were statistically nonsignificant $(p<0.05)$ at start of the experiment but remained significant at $200 \mathrm{mg}$ and $100 \mathrm{mg} / \mathrm{kg}$ with $p<0.01$. Amongst all, W. coagulans extract was more prominent in reducing analgesia with $65.3 \%(p<0.01)$ activity while the extracts of $H$. nepalensis and $Q$. dilatata showed $59.1 \%$ and $52.2 \%$ activity (Table 3 ) having $p$ value $<0.01$. P. latbenia and F. cretica remained at last with $36 \%$ and $43.4 \%$ analgesic effect, respectively. This effect was however less than that elicited by morphine $(80.0 \%)$. Hot plate assay is one of the most suitable and easy methods 


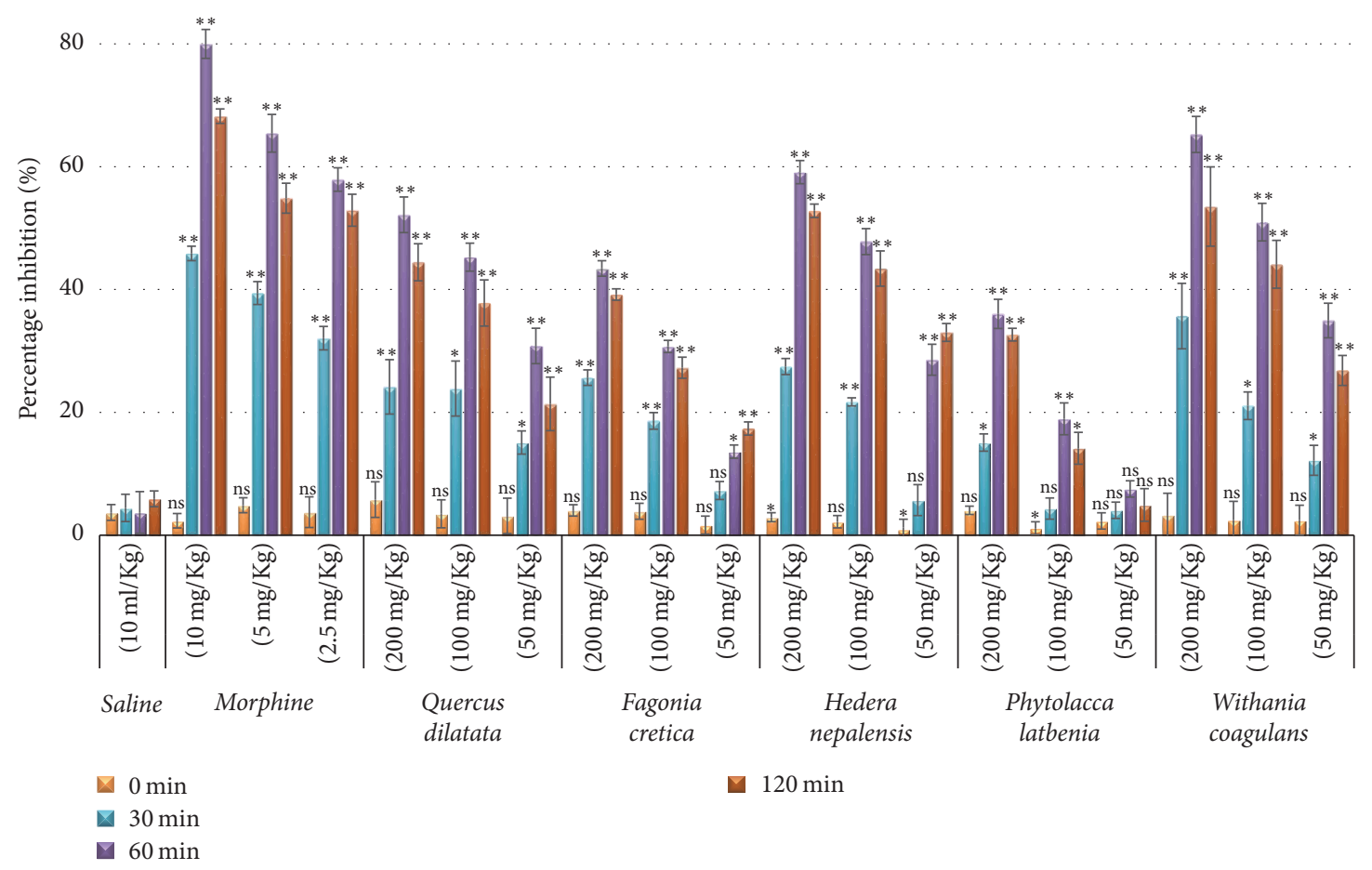

FIGURE 1: Percentage inhibition in hot plate assay at different time intervals. Values expressed in mean \pm SD with statistical significance ${ }^{*} p<$ $0.05,{ }^{* *} p<0.01$ where "ns" represents nonsignificance.

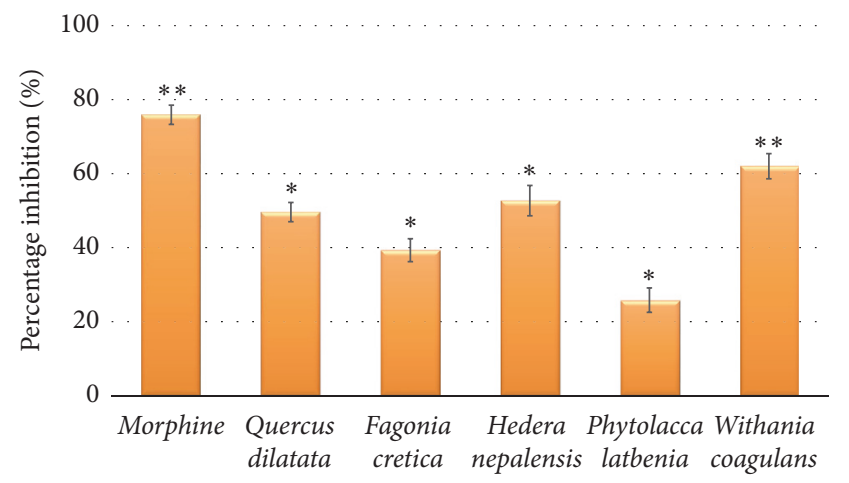

FIgURe 2: Percentage inhibition in writhing assay. Values expressed in mean $\pm \mathrm{SD}$ with statistical significance ${ }^{*} p<0.05,{ }^{* *} p<0.01$.

which represents centrally acting mechanism of pain $[45,46]$ which generally elevates the pain threshold of rodents to heat or pressure. In this study, P. latbenia and F. cretica extracts elicited low activity which suggests these extracts do not have centrally acting antinociceptive action.

3.2.2. Writhing Assay. All crude extracts were subjected to writhing assay at $200 \mathrm{mg} / \mathrm{Kg}$ to determine the peripheral antinociceptive activity and results are presented in Figure 2. The most significant activity was detected by $W$. coagulans (62.0\%; $p<0.01$ ) while $H$. nepalensis displayed $52.7 \%$ edema inhibition in statistically significant way $(p<0.05)$. Rest of the plant extracts showed $49.6 \%, 25.8 \%$, and $39.3 \%$ edema inhibition for Q. dilatata, P. latbenia, and F. cretica, respectively (Table 3 ) with $p<0.05$. The writhing assay is used for the assessment of peripherally analgesic effect which is characterized by the release of endogenous pain mediators such as arachidonic acid, cyclooxygenase, and prostaglandin [47]. Recently, flavonoids have been reported to halt prostaglandin synthetase [48]. Since prostaglandins are involved in pain perception, it can be suggested that polyphenols present in these plants may be responsible for the observed analgesic activities.

\subsection{Anti-Inflammatory Activity}

3.3.1. Carrageenan Assay. Carrageenan assay was used to assess the anti-inflammatory potential of selected medicinal plants. Carrageenan is basically linear and sulfated galactans, isolated from various marine red algae [49]. Results of edema volume measured at different time interval are presented in Table 2 which showed peak edema at $3 \mathrm{~h}$. Percentage edema inhibition was calculated from saline control and presented in Figure 3. The anti-inflammatory effect of diclofenac potassium was found increasing with passage of time being minimum in 1st hour and increased in 2nd hour and remained almost stable in 3rd and 4th hours. The behavior of plant extracts was almost similar as anti-inflammatory activity kept on increasing from first to third hour of injection and a slight decrease in activity was observed at fourth hour in concentration dependent manner (Figure 3). The comparison of the activities (Table 3) showed that the highest percentage activity was exhibited in statistically significant way by $W$. coagulans $(70.0 \% ; p<0.05)$ followed by $Q$. dilatata (66.7\%; $p<0.01)$ and H. nepalensis $(63.3 \%$; $p<0.05)$ while 
TABLE 1: Latency time in hot plate assay.

\begin{tabular}{|c|c|c|c|c|c|}
\hline \multirow{2}{*}{ Treatment } & \multirow{2}{*}{ Dose } & \multicolumn{4}{|c|}{${ }^{¥}$ Latency time $(\mathrm{sec})$} \\
\hline & & $0 \mathrm{~min}$ & $30 \mathrm{~min}$ & $60 \mathrm{~min}$ & $120 \mathrm{~min}$ \\
\hline Saline & $10 \mathrm{ml} / \mathrm{Kg}$ & $4.7 \pm 0.06$ & $4.7 \pm 0.1$ & $4.6 \pm 0.15$ & $4.8 \pm 0.06$ \\
\hline \multirow{3}{*}{ Morphine } & $10 \mathrm{mg} / \mathrm{Kg}$ & $8.7 \pm 0.10^{* *}$ & $12.4 \pm 0.10^{* *}$ & $15.3 \pm 0.20^{*}$ & $14.3 \pm 0.10^{* *}$ \\
\hline & $5 \mathrm{mg} / \mathrm{Kg}$ & $8.6 \pm 0.10^{* *}$ & $11.4 \pm 0.15^{* *}$ & $13.6 \pm 0.25^{*}$ & $12.7 \pm 0.20^{*}$ \\
\hline & $2.5 \mathrm{mg} / \mathrm{Kg}$ & $8.3 \pm 0.20^{*}$ & $10.6 \pm 0.15^{* *}$ & $12.6 \pm 0.15^{* *}$ & $12.2 \pm 0.21^{*}$ \\
\hline \multirow{3}{*}{ Quercus dilatata } & $200 \mathrm{mg} / \mathrm{Kg}$ & $7.3 \pm 0.20^{*}$ & $8.6 \pm 0.31^{*}$ & $10.5 \pm 0.20^{*}$ & $10.0 \pm 0.21^{*}$ \\
\hline & $100 \mathrm{mg} / \mathrm{Kg}$ & $6.9 \pm 0.15^{* *}$ & $8.3 \pm 0.30^{*}$ & $9.7 \pm 0.15^{* *}$ & $9.2 \pm 0.25^{*}$ \\
\hline & $50 \mathrm{mg} / \mathrm{Kg}$ & $5.5 \pm 0.15^{* *}$ & $6.1 \pm 0.10^{* *}$ & $6.9 \pm 0.15^{*}$ & $6.4 \pm 0.23^{*}$ \\
\hline \multirow{3}{*}{ Fagonia cretica } & $200 \mathrm{mg} / \mathrm{Kg}$ & $17.2 \pm 0.15^{* *}$ & $20.7 \pm 0.21^{*}$ & $23.7 \pm 0.20^{*}$ & $23.0 \pm 0.15^{* *}$ \\
\hline & $100 \mathrm{mg} / \mathrm{Kg}$ & $16.0 \pm 0.20^{*}$ & $18.3 \pm 0.21^{*}$ & $20.1 \pm 0.15^{* *}$ & $19.6 \pm 0.26^{*}$ \\
\hline & $50 \mathrm{mg} / \mathrm{Kg}$ & $14.4 \pm 0.21^{*}$ & $15.2 \pm 0.21$ & $16.1 \pm 0.15^{* *}$ & $16.7 \pm 0.15^{* *}$ \\
\hline \multirow{3}{*}{ Hedera nepalensis } & $200 \mathrm{mg} / \mathrm{Kg}$ & $16.4 \pm 0.12^{* *}$ & $20.3 \pm 0.21^{*}$ & $25.3 \pm 0.30^{*}$ & $24.3 \pm 0.17^{* *}$ \\
\hline & $100 \mathrm{mg} / \mathrm{Kg}$ & $15.5 \pm 0.15^{* *}$ & $18.5 \pm 0.10^{* *}$ & $22.5 \pm 0.32^{*}$ & $21.8 \pm 0.44^{*}$ \\
\hline & $50 \mathrm{mg} / \mathrm{Kg}$ & $10.6 \pm 0.17^{*}$ & $11.1 \pm 0.26^{*}$ & $13.5 \pm 0.26^{*}$ & $14.0 \pm 0.15^{* *}$ \\
\hline \multirow{3}{*}{ Phytolacca latbenia } & $200 \mathrm{mg} / \mathrm{Kg}$ & $15.4 \pm 0.10^{* *}$ & $17.0 \pm 0.21^{*}$ & $20.1 \pm 0.35^{*}$ & $19.6 \pm 0.15^{* *}$ \\
\hline & $100 \mathrm{mg} / \mathrm{Kg}$ & $14.8 \pm 0.15^{* *}$ & $15.2 \pm 0.25^{*}$ & $17.4 \pm 0.38^{*}$ & $16.7 \pm 0.38^{*}$ \\
\hline & $50 \mathrm{mg} / \mathrm{Kg}$ & $11.8 \pm 0.15^{* *}$ & $12.0 \pm 0.15^{* *}$ & $12.4 \pm 0.15^{* *}$ & $12.1 \pm 0.31^{*}$ \\
\hline \multirow{3}{*}{ Withania coagulans } & $200 \mathrm{mg} / \mathrm{Kg}$ & $7.3 \pm 0.25^{*}$ & $9.6 \pm 0.38^{*}$ & $11.7 \pm 0.21^{*}$ & $10.9 \pm 0.46^{*}$ \\
\hline & $100 \mathrm{mg} / \mathrm{Kg}$ & $7.0 \pm 0.21^{*}$ & $8.3 \pm 0.15^{* *}$ & $10.3 \pm 0.21^{*}$ & $9.8 \pm 0.26^{*}$ \\
\hline & $50 \mathrm{mg} / \mathrm{Kg}$ & $4.2 \pm 0.10^{* *}$ & $4.6 \pm 0.10^{* *}$ & $5.5 \pm 0.12^{* *}$ & $5.2 \pm 0.10^{* *}$ \\
\hline
\end{tabular}

${ }^{*}$ Mean values with SD expressed in ${ }^{*} p<0.05,{ }^{* *} p<0.01$ statistical significance compared with saline group.

TABLE 2: Edema volume of rat's paw in carrageenan assay.

\begin{tabular}{|c|c|c|c|c|c|}
\hline \multirow{2}{*}{ Treatment } & \multirow{2}{*}{ Dose } & \multicolumn{4}{|c|}{${ }^{¥}$ Absolute edema volume $(\mathrm{ml})$} \\
\hline & & $1 \mathrm{~h}$ & $2 \mathrm{~h}$ & $3 \mathrm{~h}$ & $4 \mathrm{~h}$ \\
\hline Saline & $10 \mathrm{ml} / \mathrm{Kg}$ & $0.24 \pm 0.02$ & $0.27 \pm 0.03$ & $0.30 \pm 0.01$ & $0.27 \pm 0.02$ \\
\hline \multirow{3}{*}{ Diclofenac potassium } & $10 \mathrm{mg} / \mathrm{Kg}$ & $0.14 \pm 0.005^{* *}$ & $0.10 \pm 0.003^{* * *}$ & $0.08 \pm 0.02^{*}$ & $0.07 \pm 0.01^{*}$ \\
\hline & $5 \mathrm{mg} / \mathrm{Kg}$ & $0.15 \pm 0.06^{*}$ & $0.14 \pm 0.002^{* *}$ & $0.09 \pm 0.05^{*}$ & $0.08 \pm 0.02^{*}$ \\
\hline & $2.5 \mathrm{mg} / \mathrm{Kg}$ & $0.16 \pm 0.04^{*}$ & $0.16 \pm 0.05^{*}$ & $0.15 \pm 0.01^{*}$ & $0.14 \pm 0.03^{*}$ \\
\hline \multirow{3}{*}{ Quercus dilatata } & $200 \mathrm{mg} / \mathrm{Kg}$ & $0.14 \pm 0.03^{*}$ & $0.14 \pm 0.04^{*}$ & $0.10 \pm 0.02^{*}$ & $0.10 \pm 0.02^{*}$ \\
\hline & $100 \mathrm{mg} / \mathrm{Kg}$ & $0.18 \pm 0.02^{*}$ & $0.17 \pm 0.03^{*}$ & $0.15 \pm 0.005^{* *}$ & $0.14 \pm 0.05^{*}$ \\
\hline & $50 \mathrm{mg} / \mathrm{Kg}$ & $0.22 \pm 0.05^{*}$ & $0.23 \pm 0.02^{*}$ & $0.20 \pm 0.06^{*}$ & $0.19 \pm 0.01^{*}$ \\
\hline \multirow{3}{*}{ Fagonia cretica } & $200 \mathrm{mg} / \mathrm{Kg}$ & $0.16 \pm 0.05^{*}$ & $0.16 \pm 0.06^{*}$ & $0.14 \pm 0.02^{*}$ & $0.14 \pm 0.005^{*}$ \\
\hline & $100 \mathrm{mg} / \mathrm{Kg}$ & $0.20 \pm 0.06^{*}$ & $0.19 \pm 0.02^{*}$ & $0.20 \pm 0.04^{*}$ & $0.19 \pm 0.05^{*}$ \\
\hline & $50 \mathrm{mg} / \mathrm{Kg}$ & $0.21 \pm 0.04^{*}$ & $0.22 \pm 0.02^{*}$ & $0.21 \pm 0.05^{*}$ & $0.22 \pm 0.03^{*}$ \\
\hline \multirow{3}{*}{ Hedera nepalensis } & $200 \mathrm{mg} / \mathrm{Kg}$ & $0.12 \pm 0.01^{*}$ & $0.13 \pm 0.01^{*}$ & $0.11 \pm 0.05^{*}$ & $0.12 \pm 0.02^{*}$ \\
\hline & $100 \mathrm{mg} / \mathrm{Kg}$ & $0.17 \pm 0.02^{*}$ & $0.16 \pm 0.03^{*}$ & $0.18 \pm 0.06^{*}$ & $0.18 \pm 0.01^{*}$ \\
\hline & $50 \mathrm{mg} / \mathrm{Kg}$ & $0.19 \pm 0.02^{*}$ & $0.20 \pm 0.04^{*}$ & $0.21 \pm 0.03^{*}$ & $0.20 \pm 0.03^{*}$ \\
\hline \multirow{3}{*}{ Phytolacca latbenia } & $200 \mathrm{mg} / \mathrm{Kg}$ & $0.16 \pm 0.02^{*}$ & $0.16 \pm 0.05^{*}$ & $0.14 \pm 0.02^{*}$ & $0.13 \pm 0.05^{*}$ \\
\hline & $100 \mathrm{mg} / \mathrm{Kg}$ & $0.16 \pm 0.02^{*}$ & $0.18 \pm 0.04^{*}$ & $0.17 \pm 0.05^{*}$ & $0.16 \pm 0.04^{*}$ \\
\hline & $50 \mathrm{mg} / \mathrm{Kg}$ & $0.20 \pm 0.03^{*}$ & $0.19 \pm 0.01^{*}$ & $0.20 \pm 0.04^{*}$ & $0.18 \pm 0.03^{*}$ \\
\hline \multirow{3}{*}{ Withania coagulans } & $200 \mathrm{mg} / \mathrm{Kg}$ & $0.14 \pm 0.01^{*}$ & $0.13 \pm 0.01^{*}$ & $0.09 \pm 0.04^{*}$ & $0.09 \pm 0.05^{*}$ \\
\hline & $100 \mathrm{mg} / \mathrm{Kg}$ & $0.18 \pm 0.06^{*}$ & $0.16 \pm 0.05^{*}$ & $0.13 \pm 0.03^{*}$ & $0.09 \pm 0.04^{*}$ \\
\hline & $50 \mathrm{mg} / \mathrm{Kg}$ & $0.20 \pm 0.05^{*}$ & $0.19 \pm 0.06^{*}$ & $0.17 \pm 0.04^{*}$ & $0.16 \pm 0.02^{*}$ \\
\hline
\end{tabular}

${ }^{*}$ Calculated from respective hour paw volume -0 hour paw volume. Expressed as mean \pm SD with ${ }^{*} p<0.05,{ }^{* *} p<0.01$, and ${ }^{* * *} p<0.001$ statistical significance compared with saline group. 


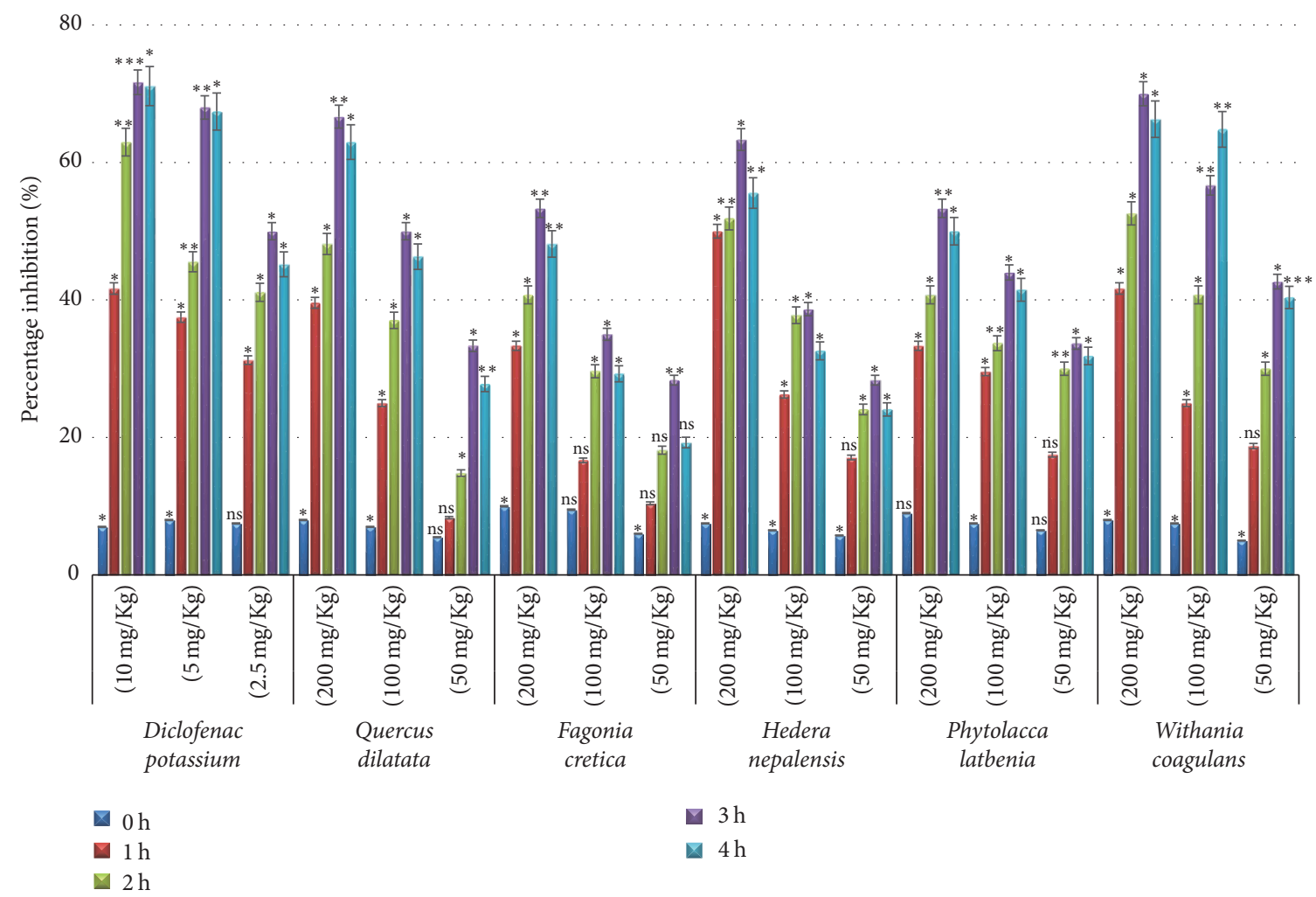

Figure 3: Percentage inhibition in carrageenan assay at different time intervals. Values expressed in mean \pm SD with statistical significance ${ }^{*} p<0.05,{ }^{* *} p<0.01$, and ${ }^{* * *} p<0.001$ where "ns" represents nonsignificance.

TABLE 3: Comparison of five plant activities in different assays.

\begin{tabular}{|c|c|c|c|c|c|c|}
\hline \multirow{3}{*}{ Crude plant extract } & \multicolumn{6}{|c|}{ Percentage Activity } \\
\hline & \multicolumn{2}{|c|}{ Analgesic assays ${ }^{*}$} & \multirow{2}{*}{ Antidepressant assay ${ }^{\S}$} & \multirow{2}{*}{ Anticoagulant assay ${ }^{\S}$} & \multicolumn{2}{|c|}{ Anti-inflammatory assays ${ }^{¥}$} \\
\hline & Hot plate & Writhing & & & Carrageenan & Histamine \\
\hline Quercus dilatata & $52.2 \%$ & $49.6 \%$ & $0 \%$ & $30.1 \%$ & $66.7 \%$ & $60.4 \%$ \\
\hline Fagonia cretica & $43.4 \%$ & $39.3 \%$ & $35.4 \%$ & $74.6 \%$ & $53.3 \%$ & $52.4 \%$ \\
\hline Hedera nepalensis & $59.1 \%$ & $52.7 \%$ & $53.4 \%$ & $73.8 \%$ & $63.3 \%$ & $63.5 \%$ \\
\hline Phytolacca latbenia & $36.0 \%$ & $25.8 \%$ & $0 \%$ & $67.3 \%$ & $53.3 \%$ & $47.4 \%$ \\
\hline Withania coagulans & $65.3 \%$ & $62.0 \%$ & $95.9 \%$ & $29.8 \%$ & $70.0 \%$ & $74.3 \%$ \\
\hline
\end{tabular}

${ }^{¥}$ Expressed as mean of highest activity. ${ }^{\S}$ Calculated from negative control group.

P. latbenia and F. cretica displayed almost same level of edema inhibition $(53.3 \% ; p<0.01)$. Carrageenan assays are generally reported as a suitable model to study antiinflammatory properties of medicinal plants as they involve several mediator molecules [50]. The inflammation process has been proposed in three phases including 1st phase $(0-1.5 \mathrm{~h})$ required for the action of mediators such as serotonin and histamine, 2 nd phase $(1.5-2.5 \mathrm{~h})$ facilitated by bradykinin, and 3rd phase $(2.5-6 \mathrm{~h})$ mediated by release of prostaglandins [51]. Our results showed significant inhibition in the 1st phase which suggests that the extracts may also inhibit the release of histamine.

3.3.2. Histamine Assay. In order to confirm the findings of carrageenan assay, the crude extracts at the most effective concentration $(200 \mathrm{mg} / \mathrm{Kg})$ of each plant were evaluated by using histamine edema model. The maximum edema inhibition was detected at 90 min (Figure 4). The most significant activity was observed by $W$. coagulans (74.3\%; $p<0.01$ ) while chlorpheniramine maleate (positive control) displayed 77\% $(p<0.01)$ edema inhibition. Q. dilatata $(60.4 \%$; $p<$ $0.05)$ and $H$. nepalensis $(63.5 \% ; p<0.01)$ showed moderate activity while $P$. latbenia and F. cretica exhibited $47.4 \%$ and $52.4 \%$ activity accordingly (Table 3 ) with statistical significance $(p<0.05)$. The results exhibited that the plant extracts have effectively reduced the inflammation produced by histamine which indicates that the extracts exhibit antiinflammatory action by inhibiting the release of histamine.

3.4. Antidepressant Activity. The depression in force swim test is categorized by increase in immobility and decrease in swimming [52]. When rats were forced to swim, they 


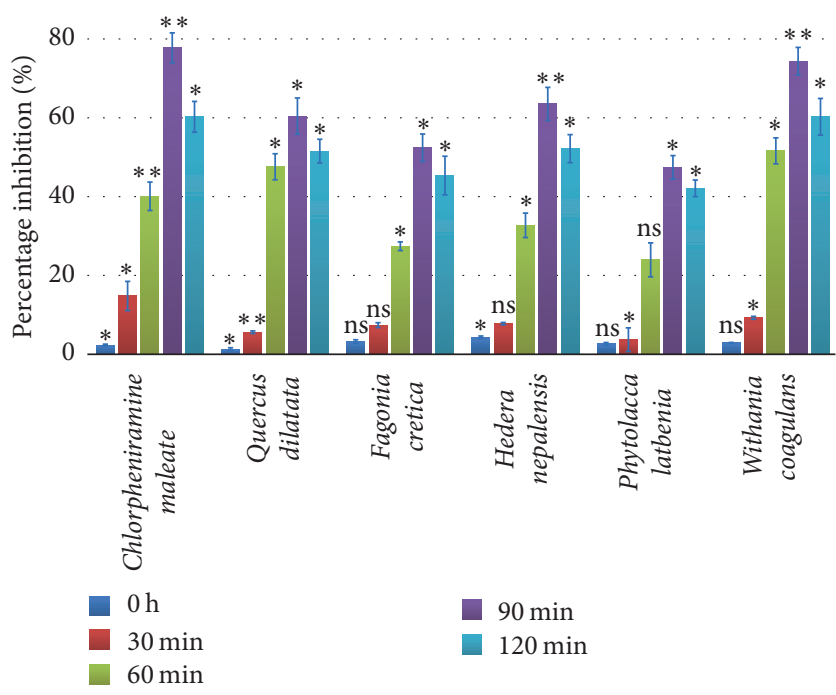

FIgUre 4: Percentage inhibition in histamine assay at different time intervals. Values expressed in mean $\pm \mathrm{SD}$ with statistical significance ${ }^{*} p<0.05,{ }^{* *} p<0.01$ where "ns" represents nonsignificance.

quickly stopped swimming and held still. This behavior was designated as immobility and showed depressed mood. The mediators that reduce this behavior are known as antidepressant [53]. The force swim test is highly specific as depression is decreased by numerous agents like tricyclics, serotonin reuptake, and MAO inhibitors [54]. Antidepressant activities of selected medicinal plants were tested by forced swim assay at three different concentration $(200,100$, and $50 \mathrm{mg} / \mathrm{Kg}$ ) and results in the form of immobility time are presented in Figure 5. Fluoxetine $\mathrm{HCl}$ and saline control showed prominent difference in mobility time ( $54.3 \mathrm{~s}$ and $14.9 \mathrm{~s}$, resp.) which represent the reliability of assay. The most prominent activity was exhibited by $W$. coagulans with immobility times $2.2 \mathrm{~s}$, $5.5 \mathrm{~s}$, and $7.4 \mathrm{~s}$ with decreasing concentration in a highly significant manner $(p<0.001)$. Approximately $95.9 \%$ activity was exhibited by the $W$. coagulans while positive control (Fluoxetine $\mathrm{HCl})$ showed $72 \%(p<0.001)$ activity as compared with saline control (Table 3 ). F. cretica and $H$. nepalensis showed moderate antidepressant activity with immobility times $35.1 \mathrm{~s}$ and $25.3 \mathrm{~s}$, respectively, at $200 \mathrm{mg} / \mathrm{Kg}$ with $p<$ 0.01 . Nonsignificant activity $(p>0.05)$ was shown by $Q$. dilatata and P. latbenia as their immobility times were $62.4 \mathrm{~s}$ and $54.6 \mathrm{~s}$ at the highest concentration accordingly. Overall results showed a significant decrease in immobility time in a concentration dependent manner. W. coagulans, F. cretica, and $H$. nepalensis are known to have different flavonoid and phenolic compounds with several biological activities in central nerves system. Although the role of flavonoids and phenolics in these plants has not been defined as antidepressant, however these compounds are well known for antidepressant effect $[7,55,56]$. So, it can be suggested that these compounds may be responsible for antidepressant effect.

3.5. Anticoagulant Activity. Anticoagulant activity of selected medicinal plants was determined by capillary method. Experiments were performed at 200, 100, and $50 \mathrm{mg} / \mathrm{Kg}$ concentrations and results are given in Figure 6. Aspirin (positive control) and saline (negative control) had blood coagulation times $71.2 \mathrm{~s}$ and $22.1 \mathrm{~s}$, respectively, which draws a clear line of difference between the anticoagulation and coagulation. Prominent and significant $(p<0.01)$ anticoagulant activity was presented by $F$. cretica and $H$. nepalensis with coagulation times of $86.9 \mathrm{~s}$ and $84.2 \mathrm{~s}$, respectively, at $200 \mathrm{mg} / \mathrm{Kg}$. However, at $100 \mathrm{mg} / \mathrm{Kg}$ coagulation times were $85.6 \mathrm{~s}$ and $79.7 \mathrm{~s}$ while at $50 \mathrm{mg} / \mathrm{Kg}$ the times were $83.8 \mathrm{~s}$ and $76.3 \mathrm{~s}$ accordingly. $P$. latbenia showed moderate but significant $(p<$ 0.05 ) antidepressant activity with coagulation times $67.5 \mathrm{~s}$, $62.8 \mathrm{~s}$, and $58.8 \mathrm{~s}$, respectively, with decreasing concentrations. Roughly, F. cretica, H. nepalensis, and P. latbenia showed $74.6 \%, 73.8 \%$, and $67.3 \%$ enhanced activity with $p$ value less than 0.01 as compared with saline control $(0 \%)$ while Aspirin exhibited 69.0\% $(p<0.001)$ activity (Table 3$)$. The blood coagulation time of $Q$. dilatata (31.8s; $p<0.01$ ) and $W$. coagulans $(31.5 s ; p<0.01)$ was about equal to saline control (22.1s) representing neutral behavior of these plant extracts. Coagulation of blood can be delayed by numerous agents in blood, having different mode of actions. Most of them depend on the inhibition of clotting factors which are major cause of heart attacks and strokes [57]. Activation of antithrombin-III is the one the mechanisms and anticoagulant drugs like Lepirudin, Dalteparin, and Fondaparinux are the other $[58,59]$. To cope with such problems herbal products or medicines can be used instead of blood thinners. The promising anticoagulant effect of F. cretica, H. nepalensis, and P. latbenia opens the doors for the further mechanism of action study in herbal medicines.

\section{Conclusion}

The hot plate assay is a simple method of the pain reaction in animals by which effectiveness of analgesics can be tested by measuring the heat induced pain response. Conversely, if a condition such as an inflammation of the paw serves to decrease the response latency, it is said to induce hyperalgesia which means these assays have some positive correlation between them. In contrast forced swim test and anticoagulant assays are unrelated so no correlation can be found between them. Forced swimming test represents the pharmacological model and produces a state similar to human depression which is very specific and sensitive while anticoagulant assay deals with the hemostatic mechanisms.

From the results of biological screening on rats it was concluded that $Q$. dilatata showed moderate activity in antinflammatory and analgesic assay. The crude extract of $F$. cretica exhibited prominent activity in anticoagulant assay while $P$. latbenia extracts showed moderate activity only in antidepressant assay. $H$. nepalensis showed positive results in all assays which represents the multidrug potential of this plant. As far as the extract of $W$. coagulans is concerned most promising results were exhibited by this plant in terms of in anti-inflammatory, analgesic, and antidepressant property. So, overall comparison of all the plant extracts showed that $W$. coagulans and $H$. nepalensis are the most gifted plants and have good potential for further studies.

\section{Conflicts of Interest}

The authors declare no financial conflicts of interest. 


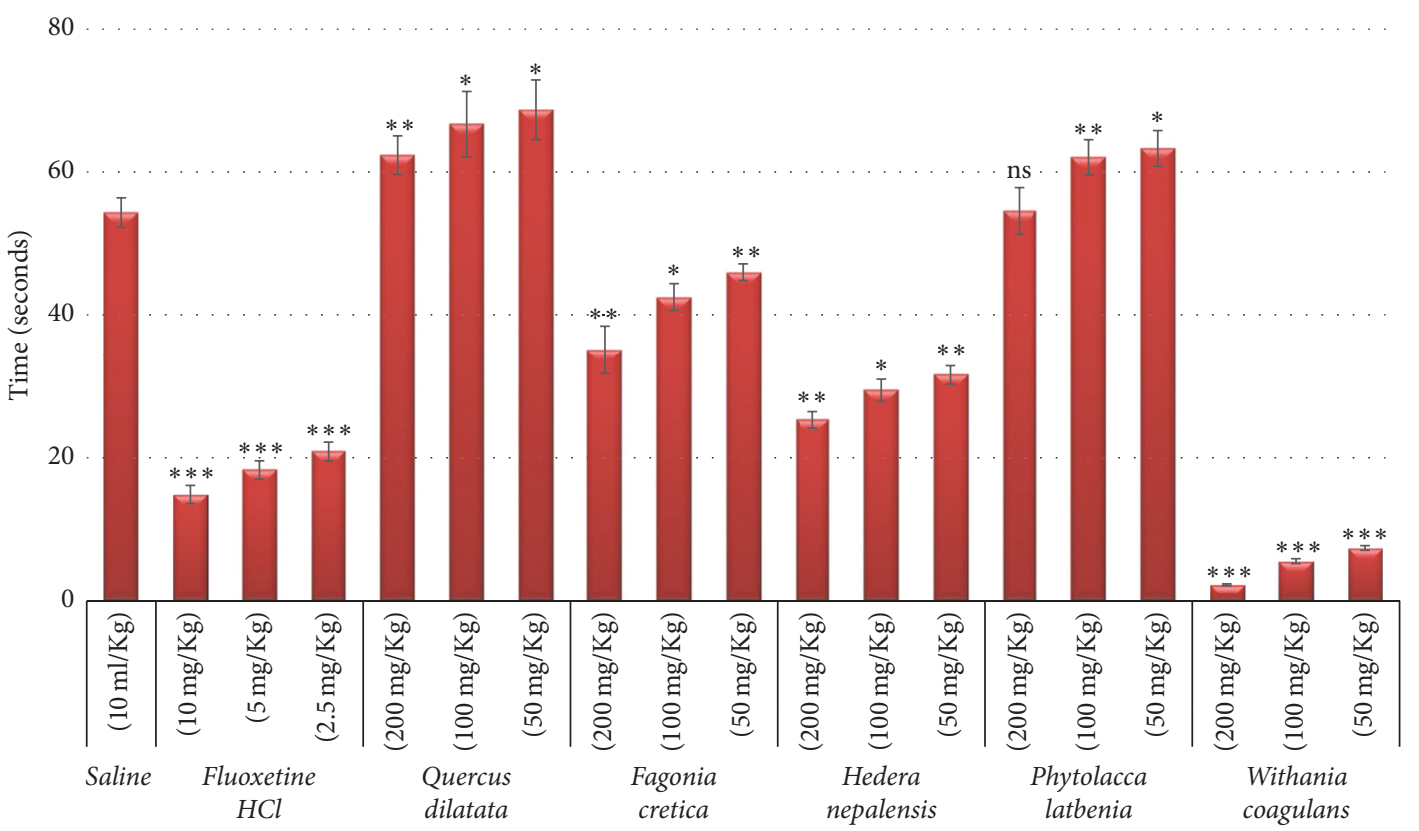

FIGURE 5: Results of antidepressant assay. Values expressed in mean \pm SD with statistical significance ${ }^{*} p<0.05,{ }^{* *} p<0.01$, and ${ }^{* * *} p<0.001$ where "ns" represents nonsignificance.

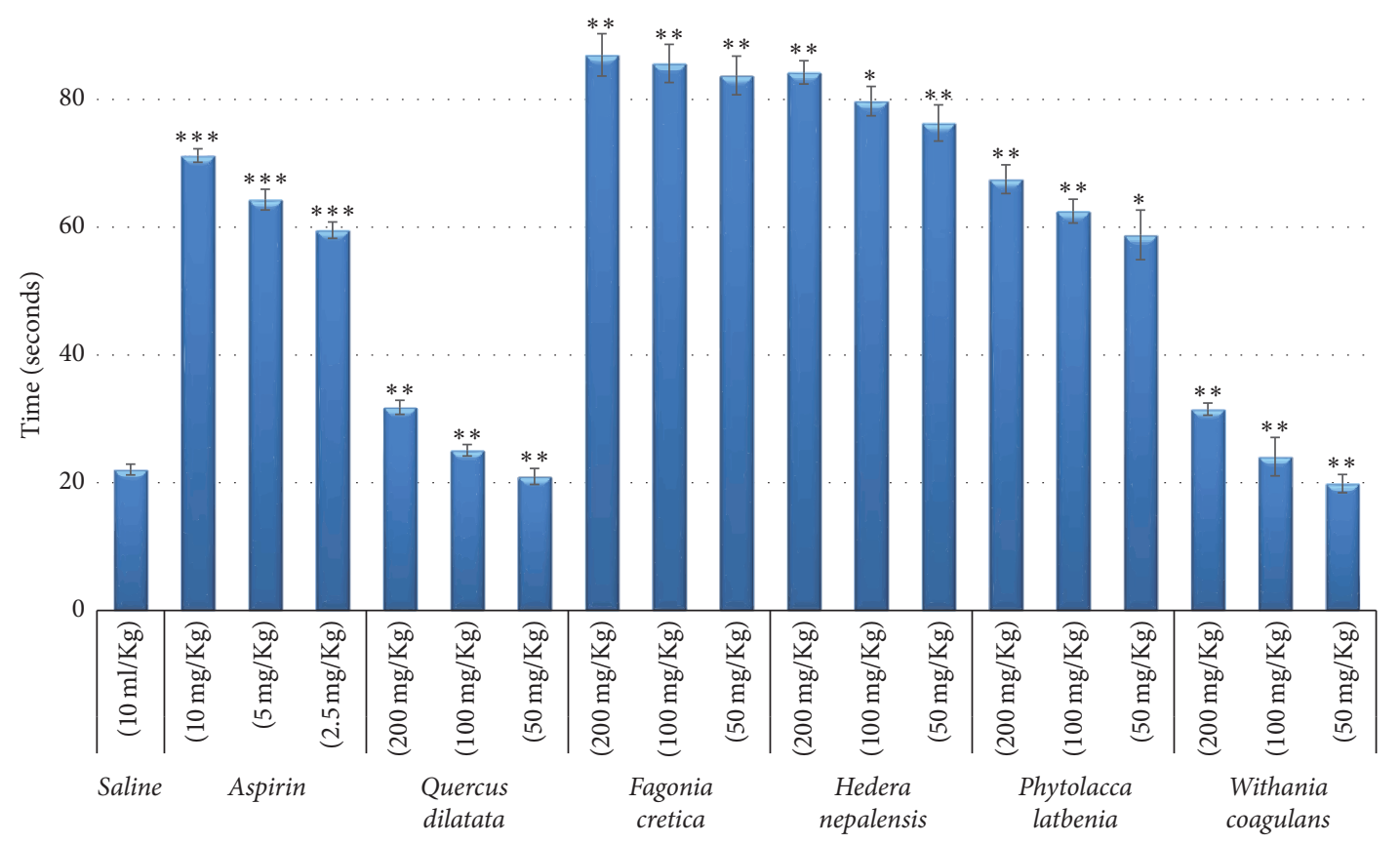

Figure 6: Results of anticoagulant assay. Values expressed in mean \pm SD with statistical significance ${ }^{*} p<0.05,{ }^{* *} p<0.01$, and ${ }^{* * *} p<0.001$.

\section{Authors' Contributions}

Hammad Ismail contributed in anti-inflammatory and analgesic assays and drafted the manuscript. Ammara Rasheed, Laila Jafri, Nazif Ullah, and Ihsan ul Haq carried out anti-inflammatory, antidepressant, and anticoagulant assays. Moniba Sajid and Erum Dilshad performed analgesic assays. Bushra Mirza conceived the study design, supervised the study, and reviewed and approved the final version of manuscript.

\section{Acknowledgments}

The authors are highly grateful to the animal house staff for their support and facilitation. 


\section{References}

[1] N. Ullah, "Medicinal plants of Pakistan: Challenges and Opportunities," Journal of Complementary \& Alternative Medici, vol. 6, no. 4, p. 00193, 2017.

[2] G. M. Cragg, D. J. Newman, and K. M. Snader, "Natural products in drug discovery and development," Journal of Natural Products, vol. 60, no. 1, pp. 52-60, 1997.

[3] S.-Y. Pan, S.-F. Zhou, S.-H. Gao et al., "New perspectives on how to discover drugs from herbal medicines: CAM'S outstanding contribution to modern therapeutics," Evidence-Based Complementary and Alternative Medicine, vol. 2013, Article ID 627375, 25 pages, 2013.

[4] H. Azaizeh, B. Saad, K. Khalil, and O. Said, "The state of the art of traditional Arab herbal medicine in the Eastern region of the Mediterranean: a review," Evidence-Based Complementary and Alternative Medicine, vol. 3, no. 2, pp. 229-235, 2006.

[5] S.-Y. Yin, W.-C. Wei, F.-Y. Jian, and N.-S. Yang, "Therapeutic applications of herbal medicines for cancer patients," EvidenceBased Complementary and Alternative Medicine, vol. 2013, Article ID 302426, 15 pages, 2013.

[6] M. Sajid, M. R. Khan, N. A. Shah et al., "Phytochemical, antioxidant and hepatoprotective effects of Alnus nitida bark in carbon tetrachloride challenged Sprague Dawley rats," $B M C$ Complementary and Alternative Medicine, vol. 16, no. 1, article no. 268, 2016.

[7] E. Dilshad, H. Ismail, I.-U. Haq et al., "Rol genes enhance the biosynthesis of antioxidants in Artemisia carvifolia Buch," BMC Plant Biology, vol. 16, no. 1, article no. 125, 2016.

[8] E. Ahmed, M. Arshad, M. Ahmad, M. Saeed, and M. Ishaque, "Ethnopharmacological survey of some medicinally important plants of Galliyat Areas of NWFP, Pakistan," Asian Journal of Plant Sciences, vol. 3, no. 4, pp. 410-415, 2004.

[9] S. Shah, "Pollen morphology of three species of quercus (Family Fagaceae) [Quercus dilatata, Q. incana and Q. ballota]," Journal of Agriculture and Social Sciences, vol. 1, pp. 359-360, 2005.

[10] F. Haq, H. Ahmad, and M. Alam, "Traditional uses of medicinal plants of Nandiar Khuwarr catchment (District Battagram), Pakistan," Journal of Medicinal Plants Research, vol. 5, no. 1, pp. 39-48, 2011.

[11] M. Ihtisham, Ihsan-Ul-Haq, S. Sarwar, and B. Mirza, "HPLCDAD analysis and free radical scavenging potential of Quercus dilatata L," Pakistan Journal of Botany, vol. 45, pp. 577-581, 2013.

[12] S. P. Umachigi, K. N. Jayaveera, C. K. Ashok Kumar, G. S. Kumar, B. M. Vrushabendra swamy, and D. V. Kishore Kumar, "Studies on Wound Healing Properties of Quercus infectoria," Tropical Journal of Pharmaceutical Research, vol. 7, no. 1, pp. 913-919, 2008.

[13] A. Hussain, M. Zia, and B. Mirza, "Cytotoxic and antitumor potential of Fagonia cretica L," Turkish Journal of Biology, vol. 31, no. 1, pp. 19-24, 2007.

[14] S. R. Baquar, Medicinal and poisonous plants of Pakistan, Karachi, Printas, 1989.

[15] H. M. Said, "Hammardad pharmacopoeia of Easteren Medicine," in Institute of Health and Tibbi Research, Pakistan, Karachi, 1969.

[16] M. Tahir Razi, M. H. H. B. Asad, T. Khan et al., "Antihaemorrhagic potentials of Fagonia cretica against Naja naja karachiensis (black Pakistan cobra) venom," Natural Product Research (Formerly Natural Product Letters), vol. 25, no. 20, pp. 19021907, 2011.
[17] U. Singh, A. Wadhwani, and B. Johri, "Dictionary of economic plants in India," in Dictionary of Economic Plants in India, 2 edition, 1983.

[18] V. S. Kasture, S. A. Gosavi, J. B. Kolpe, and S. G. Deshapande, "Phytochemical and biological evaluation of Fagonia species: a review," World Journal of Pharmacy and Pharmaceutical Sciences, vol. 3, no. 5, pp. 1206-1217, 2014.

[19] H. M. Said and A. Saeed, Medicinal herbal a textbook for medical students and doctors, Hamdard Foundation Nazimabad, Karachi, Pakistan, 1996.

[20] S. S. Ahmad, "Medicinal wild plants from Lahore-Islamabad motorway (M-2)," Pakistan Journal of Botany, vol. 39, no. 2, pp. 355-375, 2007.

[21] A. Bashir, M. Nida, B. Shumaila, A. Sadiq, K. Ibrar, and A. Mohammad, "Biological screening of Hedera nepalensis," Journal of Medicinal Plants Research, vol. 6, no. 39, pp. 52505257, 2012.

[22] M. Hamayun, S. A. Khan, E. Y. Sohn, and I.-J. Lee, "Folk medicinal knowledge and co nservation status of some economically valued medicinal plants of district Swat, Pakistan," Lyonia, vol. 11, no. 2, pp. 101-113, 2006.

[23] R. A. Qureshi, M. A. Ghufran, S. A. Gilani, Z. Yousaf, G. Abbas, and A. Batool, "Indigenous medicinal plants used by local women in southern Himalayan regions of Pakistan," Pakistan Journal of Botany, vol. 41, no. 1, pp. 19-25, 2009.

[24] R. A. Qureshi, M. A. Ghufran, S. A. Gilani, K. Sultana, and M. Ashraf, "Ethnobotanical studies of selected medicinal plants of sudhan gali and ganga chotti hills, district bagh, azad kashmir," Pakistan Journal of Botany, vol. 39, no. 7, pp. 2275-2283, 2007.

[25] S. A. Gilani, R. A. Qureshi, and S. J. Gilani, "Indigenous uses of some important ethnomedicinal herbs of Ayubia National Park, Abbottabad, Pakistan," Ethnobotanical Leaflets, vol. 2006, no. 1, p. 32, 2006.

[26] G. M. Shah and M. A. Khan, "Checklist of Medicinal Plants of Siran Valley, Mansehra, Pakistan," Ethnobotanical Leaflets, vol. 2006, no. 1, p. 6, 2006.

[27] N. Ullah, I. U. Haq, N. Safdar, and B. Mirza, "Physiological and biochemical mechanisms of allelopathy mediated by the allelochemical extracts of Phytolacca latbenia (Moq.) H. Walter," Toxicology \& Industrial Health, vol. 31, no. 10, pp. 931-937, 2015.

[28] N. Ullah, I.-U. Haq, and B. Mirza, "Phytotoxicity evaluation and phytochemical analysis of three medicinally important plants from Pakistan," Toxicology \& Industrial Health, vol. 31, no. 5, pp. 389-395, 2015.

[29] O. K. Yong, J. D. Johnson, and J. L. Eun, "Phytotoxic effects and chemical analysis of leaf extracts from three Phytolaccaceae species in South Korea," Journal of Chemical Ecology, vol. 31, no. 5, pp. 1175-1186, 2005.

[30] R. B. Tareen, T. Bibi, M. A. Khan, M. Ahmad, and M. Zafar, "Indigenous knowledge of folk medicine by the women of Kalat and Khuzdar regions of Balochistan, Pakistan," Pakistan Journal of Botany, vol. 42, no. 3, pp. 1465-1485, 2010.

[31] P. C. Gupta, "Withania coagulans Dunal- An overview," International Journal of Pharmaceutical Sciences Review and Research, vol. 12, no. 2, pp. 68-71, 2012.

[32] S. Naz, T. Masud, and M. A. Nawaz, "Characterization of milk coagulating properties from the extract of Withania coagulans," International Journal of Dairy Technology, vol. 62, no. 3, pp. 315320, 2009.

[33] M. Ullah, M. U. Khan, A. Mahmood et al., "An ethnobotanical survey of indigenous medicinal plants in Wana district south 
Waziristan agency, Pakistan," Journal of Ethnopharmacology, vol. 150, no. 3, pp. 918-924, 2013.

[34] V. Gupta and B. B. Keshari, "Withania coagulans Dunal (paneer doda): A review," International Journal of Ayurvedic and Herbal Medicine, vol. 3, no. 5, pp. 1130-1136, 2013.

[35] R. Maurya, Akanksha, and Jayendra, "Chemistry and pharmacology of Withania coagulans: An Ayurvedic remedy," Journal of Pharmacy and Pharmacology, vol. 62, no. 2, pp. 153-160, 2010.

[36] Atta-ur-Rahman, Dur-e-Shahwar, A. Naz, and M. I. Choudhary, "Withanolides from Withania coagulans," Phytochemistry, vol. 63, no. 4, pp. 387-390, 2003.

[37] M. Khodaei, M. Jafari, and M. Noori, "Remedial Use of Withanolides from Withania Coagolans (Stocks) Dunal," Advances in Life Sciences, vol. 2, no. 1, pp. 6-19, 2012.

[38] H. Ismail, E. Dilshad, M. T. Waheed, M. Sajid, W. K. Kayani, and B. Mirza, "Transformation of Lactuca sativa L. with rol C gene results in increased antioxidant potential and enhanced analgesic, anti-inflammatory and antidepressant activities in vivo," 3 Biotech, vol. 6, no. 2, article no. 215, 2016.

[39] M. Abdollahi, H. Karimpour, and H. R. Monsef-Esfehani, "Antinociceptive effects of Teucrium polium L. total extract and essential oil in mouse writhing test," Pharmacological Research, vol. 48, no. 1, pp. 31-35, 2003.

[40] S. C. Jain, R. Jain, R. A. Sharma, and F. Capasso, "Pharmacological investigation of Cassia italica," Journal of Ethnopharmacology, vol. 58, no. 2, pp. 135-142, 1997.

[41] H. Ismail, E. Dilshad, M. T. Waheed, and B. Mirza, “Transformation of Lettuce with rol ABC Genes: Extracts Show Enhanced Antioxidant, Analgesic, Anti-Inflammatory, Antidepressant, and Anticoagulant Activities in Rats," Applied Biochemistry and Biotechnology, vol. 181, no. 3, pp. 1179-1198, 2017.

[42] M. Sajid, M. R. Khan, S. A. Shah et al., "Investigations on antiinflammatory and analgesic activities of Alnus nitida Spach (Endl). stem bark in Sprague Dawley rats," Journal of Ethnopharmacology, vol. 198, pp. 407-416, 2017.

[43] H. Ismail and B. Mirza, "Evaluation of analgesic, anti-inflammatory, anti-depressant and anti-coagulant properties of Lactuca sativa (CV. Grand Rapids) plant tissues and cell suspension in rats," BMC Complementary and Alternative Medicine, vol. 15, no. 1, article no. 199, 2015.

[44] A. Gunn, E. N. Bobeck, C. Weber, and M. M. Morgan, "The influence of non-nociceptive factors on hot-plate latency in rats," The Journal of Pain, vol. 12, no. 2, pp. 222-227, 2011.

[45] H. Khan, M. Saeed, A. U. H. Gilani, M. A. Khan, I. Khan, and N. Ashraf, "Antinociceptive activity of aerial parts of Polygonatum verticillatum: attenuation of both peripheral and central pain mediators," Phytotherapy Research, vol. 25, no. 7, pp. 1024-1030, 2011.

[46] T. Yaseen, M. Ibrar, Barkatullah., and N. Muhammad, "Antinociceptive and laxative profile of Withania coagulans leaves," Medicinal Chemistry \& Drug Discovery, vol. 4, no. 1, pp. 41-46, 2013.

[47] E. M. Franzotti, C. V. F. Santos, H. M. S. L. Rodrigues, R. H. V. Mourão, M. R. Andrade, and A. R. Antoniolli, "Anti-inflammatory, analgesic activity and acute toxicity of Sida cordifolia L. (Malva-branca)," Journal of Ethnopharmacology, vol. 72, no. 1-2, pp. 273-277, 2000.

[48] M. H. Hugar, K. M. Hosamani, and M. D. Liyakath Ahmed, "Phytochemical and pharmacological studies of ethanol extract of Dalbergia sissoo seeds: An approach for the in-vivo analgesic and antipyretic activities," International Journal of Pharma and Bio Sciences, vol. 1, no. 4, article no. 31, 2010.
[49] D. A. Navarro and C. A. Stortz, "Microwave-assisted alkaline modification of red seaweed galactans," Carbohydrate Polymers, vol. 62, no. 2, pp. 187-191, 2005.

[50] W. Mequanint, E. Makonnen, and K. Urga, "In vivo antiinflammatory activities of leaf extracts of Ocimum lamiifolium in mice model," Journal of Ethnopharmacology, vol. 134, no. 1, pp. 32-36, 2011.

[51] M. di Rosa, J. P. Giroud, and D. A. Willoughby, "Studies on the mediators of the acute inflammatory response induced in rats in different sites by carrageenan and turpentine," The Journal of Pathology, vol. 104, no. 1, pp. 15-29, 1971.

[52] L. G. Kirby and I. Lucki, "Interaction between the forced swimming test and fluoxetine treatment on extracellular 5hydroxytryptamine and 5-hydroxyindoleacetic acid in the rat," The Journal of Pharmacology and Experimental Therapeutics, vol. 282, no. 2, pp. 967-976, 1997.

[53] R. D. Porsolt, A. Bertin, N. Blavet, M. Deniel, and M. Jalfre, "Immobility induced by forced swimming in rats: Effects of agents which modify central catecholamine and serotonin activity," European Journal of Pharmacology, vol. 57, no. 2-3, pp. 201-210, 1979.

[54] M. J. Detke, M. Rickels, and I. Lucki, "Active behaviors in the rat forced swimming test differentially produced by serotonergic and noradrenergic antidepressants," Psychopharmacology, vol. 121, no. 1, pp. 66-72, 1995.

[55] Y. Velioglu and G. Mazza, "Characterization of flavonoids in petals of Rosa damascena by HPLC and spectral analysis," Journal of Agricultural and Food Chemistry, vol. 39, no. 3, pp. 463-467, 1991.

[56] S. A. Moallem, H. Hosseinzadeh, and F. Ghoncheh, "Evaluation of antidepressant effects of aerial parts of Echium vulgare on mice," Iranian Journal of Basic Medical Sciences, vol. 10, no. 3, pp. 189-196, 2007.

[57] T. W. Meade, V. Ruddock, Y. Stirling, R. Chakrabarti, and G. J. Miller, "Fibrinolytic activity, clotting factors, and long-term incidence of ischaemic heart disease in the Northwick Park Heart Study," The Lancet, vol. 342, no. 8879, pp. 1076-1079, 1993.

[58] S. Chackalamannil, “Thrombin receptor (protease activated receptor-1) antagonists as potent antithrombotic agents with strong antiplatelet effects," Journal of Medicinal Chemistry, vol. 49, no. 18, pp. 5389-5403, 2006.

[59] S. Moll and H. R. Roberts, "Overview of anticoagulant drugs for the future," Seminars in Hematology, vol. 39, no. 3, pp. 145-157, 2002. 


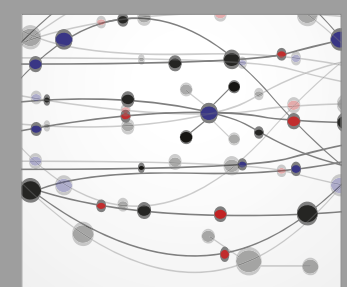

The Scientific World Journal
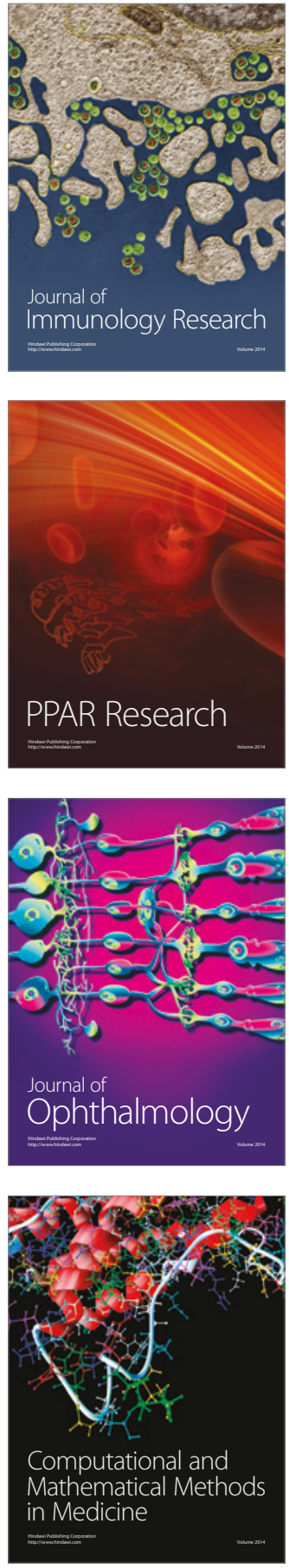

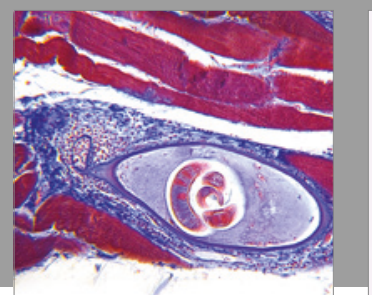

Gastroenterology Research and Practice
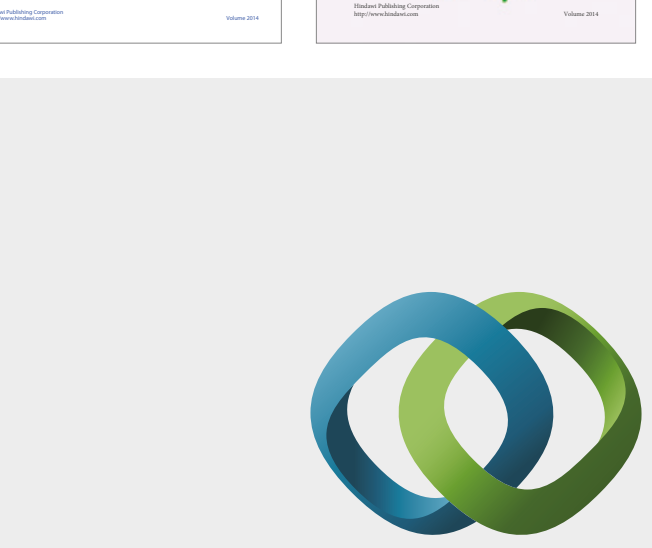

\section{Hindawi}

Submit your manuscripts at

https://www.hindawi.com
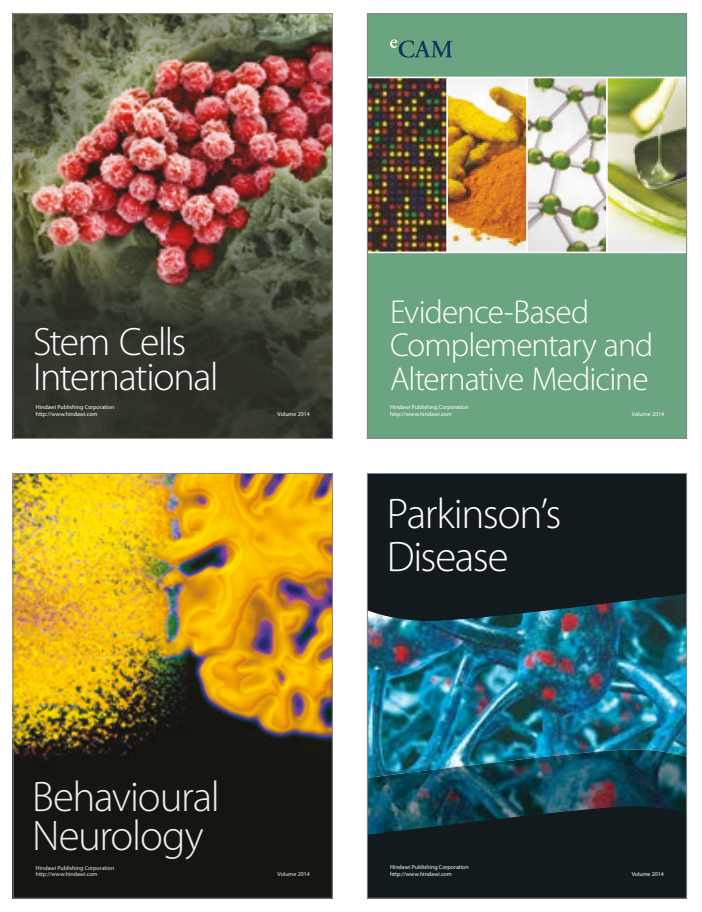
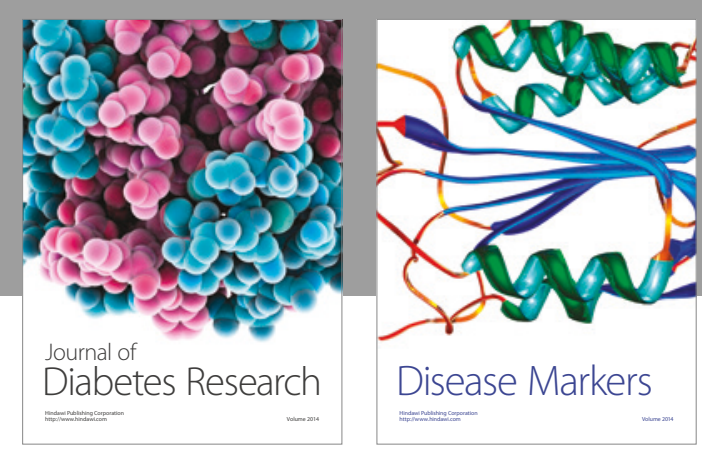

Disease Markers
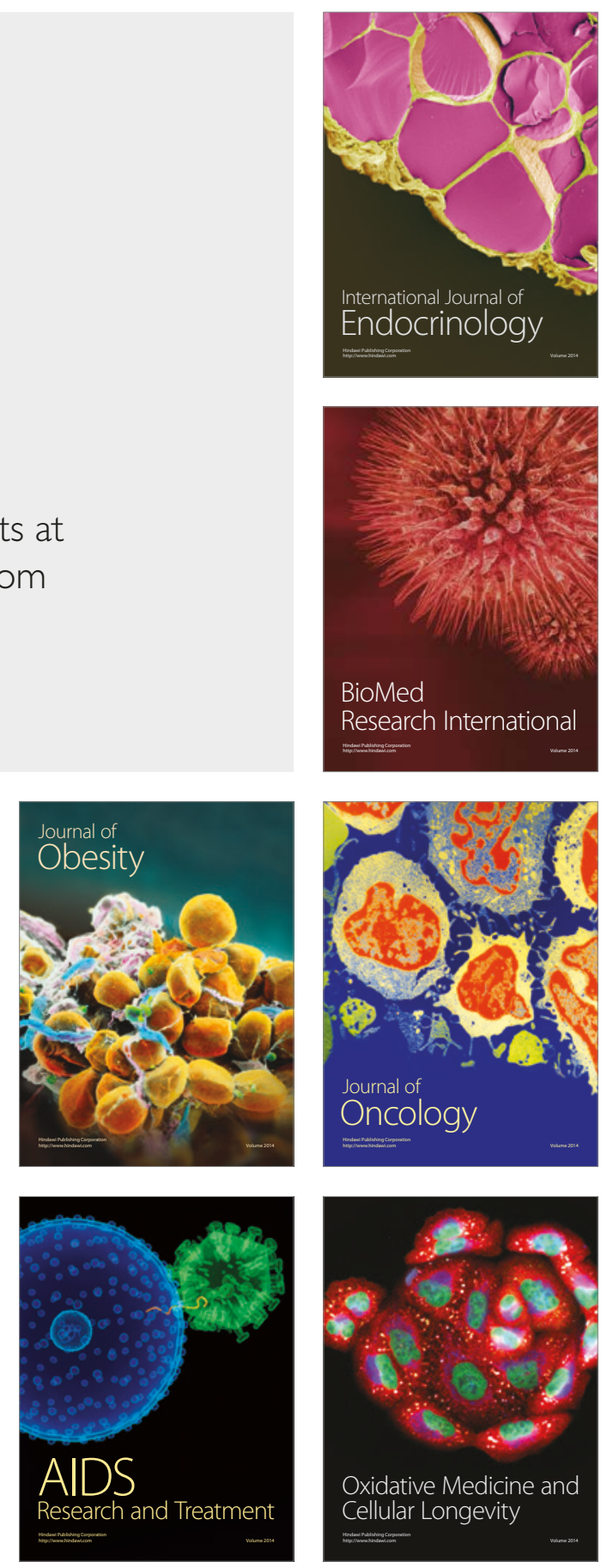